\title{
Histological Considerations of Direct Pulp Capping Agents
}

\author{
D. R. HEYS, C. F. COX, R. J. HEYS, and J. K. AVERY
}

Laboratory of Oral Histology, School of Dentistry, The University of Michigan, Ann Arbor, Michigan 48109

The results from this study showed a variety of pulpal responses to various calcium hydroxide materials when placed directly on the dental pulp. Two of the materials proved to be more successful at stimulating reparative dentin bridging and healing of the underlying pulp tissue. The remainder of the pulp capping agents were ineffective at healing the pulp and forming a reparative dentin bridge. When teeth were capped with these other agents, the pulp showed necrosis and chronic inflammation.

J Dent Res 60(7): 1371-1379, July 1981

\section{Introduction.}

Ever since dentistry has dealt with tooth decay, it has been searching for a medicament which, when placed in direct contact with exposed pulp, would result in a reparative dentin bridge and pulp healing. Many different compounds have been used; zinc oxide eugenol ${ }^{1-9}$ has been studied and reported to result in little, if any, reparative dentin bridge formation. In several reports ${ }^{4,9}$ a chronic inflammatory response may persist for some time. Polyacrylates $9-11$ have also been studied, and results similar to those for zinc oxide eugenol were found. The most successful and most widely tested product to date consists of variations of the compound calcium hydroxide $\mathrm{Ca}(\mathrm{OH})_{2} .^{12-18}$ Many investigators have used $\mathrm{Ca}(\mathrm{OH})_{2}+\mathrm{H}_{2} \mathrm{O}$ and found a high success rate with the formation of reparative dentin bridging over the exposure site. This bridging, however, occurred at varying distances from the exposure site due to a zone of necrotic tissue developing at the contact site. Various commercial products have been tested: Hydrex, ${ }^{4,11,19-21}$ for example, formed inconsistent dentinal bridges, while $\mathrm{MPC}^{9,11,18}$ showed a lack of dentin bridge formation. Pulpdent, $9,18,20,22,23 \mathrm{Ca}(\mathrm{OH})_{2}$ in a methyl

Received for publication July 18,1980

Accepted for publication October 17, 1980 cellulose paste, and Calxyl ${ }^{24-27}$ have been reported effective in dentin bridge formation; however, associated marginal necrosis in the pulp has also been observed. The most widely used calcium hydroxide at this time - one of the most effective in dentin bridge formation on exposed non-inflamed dental pulps-is the compound Dycal. This compound $9,10,18,20,28,29$ produces a high percentage of reparative dentin bridging at the site of application. Recently, work done with the use of antibiotics plus $\mathrm{Ca}(\mathrm{OH})_{2} 30,31$ has been reported to enhance the effectiveness and success rate of dentin bridge formation. Another area of recent interest is the work done on tricalcium phosphate (Synthos), ${ }^{34}$ which has been reported to produce a better success rate than $\mathrm{Ca}(\mathrm{OH})_{2}$ plus saline for the same period.

The purpose of this study was to histologically evaluate a variety of compounds to determine if an improved pulp capping compound could be developed.

\section{Materials and methods.}

This study observed the histopathological response of 12 compounds used as pulp capping agents in four adult thesus monkeys after eight wk. All animals were initially sedated with approximately $1 \mathrm{cc}$ of an intramuscular injection of Ketalar* and additional anesthesia, and muscle relaxation was obtained with approximately $1.0-1.5 \mathrm{cc}$ of sodium pentobarbital injected intravenously. This afforded several hours of anesthesia.

A single Class $\mathrm{V}$ cavity preparation was placed on the buccal surfaces of both anterior and posterior teeth with a \#35 carbide inverted cone bur which was changed after every fourth tooth. High-speed air turbine (approximately $250,000 \mathrm{rpm}$ ) with water spray was used to prepare the cavity by removing the dentin until a very thin pulpal floor remained. A sterile explorer was then

*Parke-Davis \& Co., Detroit, MI 48232 
used to enter the pulp and reflect the thin window of dentin. Bleeding of the pulp was controlled by a sterile cotton pellet. The medicament of choice was then carefully placed on the exposure site and allowed to set. The remaining preparation was then filled with amalgam. Each compound was placed in eight teeth which were randomly situated in both anterior and posterior positions of the mandible and maxilla and randomly distributed throughout the four monkeys.

All teeth were tested for a period of eight wk, after which time the monkeys were then perfused using left ventricular vascular perfusion of normal saline followed by alcohol-formalin acetic-acid (AFA) fixative. ${ }^{32}$ The jaws were dissected free; the teeth were surgically exposed by removal from the buccal bone plate and were carefully elevated from the socket. The apical onethird of each root was carefully removed with a surgical bur, and the tooth was then placed in AFA. The teeth were decalcified in formic acid sodium citrate, and the end point of decalcification was determined by radiographic observation. The teeth were then dehydrated, embedded in paraffin, sectioned at $8 \mu \mathrm{m}$, and stained with hematoxylin and eosin. The histological response was graded according to Mjör and Tronstad ${ }^{33}$ as slight, moderate, or severe. The following materials were used: Material 1) Experimental Life," Material 2) Dycal, $\S$ Material 3) MPC, $\dagger$ Material 4) Synthos $\#$ plus saline covered by MPC, Material 5) Tricalcium phosphate plus saline covered by MPC, Material 6) Zinc oxide plus saline covered by MPC, Material 7) Zinc oxide - C-AMP $\ddagger$ plus saline covered by MPC, Material 8) Zinc oxide - C-AMP plus saline covered by MPC catalyst, Material 9) $\mathrm{Ca}(\mathrm{OH})$ plus saline covered by MPC, Material 10) Synthos plus saline covered by MPC catalyst, Material 11) Tricalcium phosphate plus saline covered by MPC catalyst, and Material 12) Zinc oxide plus saline covered by MPC catalyst. Synthos, Tricalcium phosphate, Zinc oxide, and Cyclic AMP were each mixed with saline to form a slurry paste.

\footnotetext{
*Kerr Mfg. Co., Romulus, MI 48174

§ L.D. Caulk, Milford, DE 19963

$\dagger$ Kerr Mfg. Co., Romulus, MI 48174

\#Miter, Inc., Worthington, OH 43805

$\mp$ Sigma Chemical Co., St. Louis, MO 63178
}

All materials were placed in the base of the cavity preparations and allowed to set; the remainder of the cavity preparation was restored with amalgam.

\section{Results.}

Material \#1. - Six of the eight teeth showed evidence of some dentin bridge formation; the two remaining tooth pulps had chronic inflammation adjacent to the pulpal tissue underlying the exposure, with one demonstrating a moderate pulpal response and one a severe response. Incomplete dentin bridges were present in two of the eight teeth. Of these, one had a bridge that was almost complete; however, there was a small void, and under it was a small zone of chronic inflammatory cells and hyperemia. The other case had a poorly formed, very thin bridge of irregular dentin which was tubular in nature. The inflammatory response was moderate, extending into the coronal pulp lateral to the exposure. Four teeth had complete continuous dentin bridges covering the exposure site. In one case the dentin bridge was nontubular in nature, while the other three bridges exhibited tubular dentin in the original reparative dentin deposited. Fig. 1 illustrates an ideal dentin bridge of tubular reparative dentin directly adjacent to the medicament interface. The pulpal tissue beneath this bridge showed few inflammatory cells, with only a minimal increase in vascularity.

Material \#2. - In two of eight teeth no dentin bridging was evident, and the inflammatory response was limited to the area underlying the exposure with some lateral involvement of the surrounding pulpal tissue. In three teeth bridging was incomplete, and small voids appeared in the bridge. In these areas there was a persistent inflammatory response remaining at eight wk. The incomplete bridge was composed of dentin which was irregular in nature, with some cellular inclusions and fragments of dentin chips from the original operative procedure. The odontoblastic cell layer appeared shortened and, in some instances, did not appear, with darker staining cytoplasm; in other teeth the cells were elongated. The three remaining teeth had complete dentin bridges, adjacent to the medicament interface, which were composed of irregular dentin with some entrapped cells and 


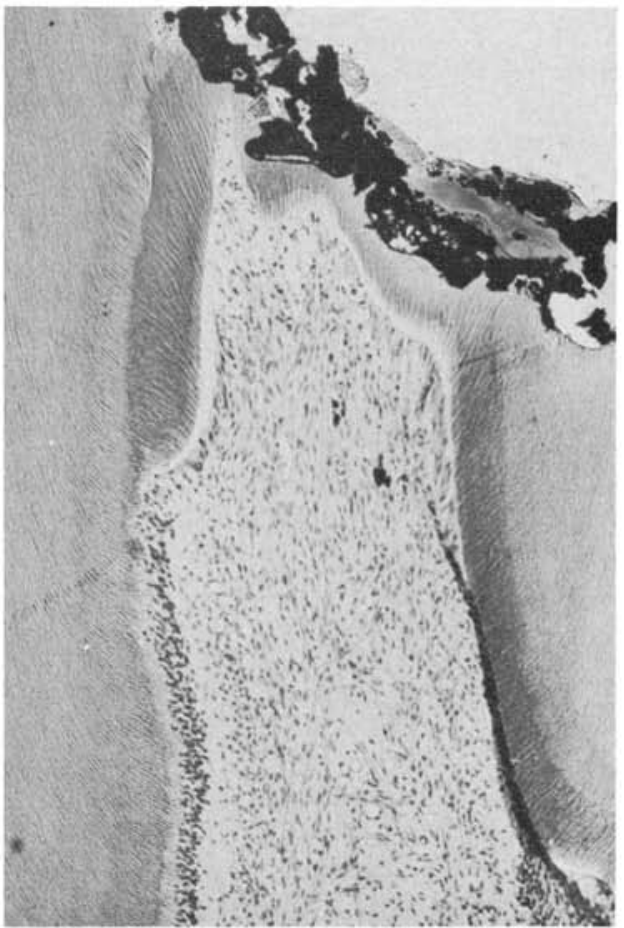

Fig. 1 - Material \#1. This shows a lower power view of a tubular reparative dentin bridge adjacent to the medicament interface. The underlying pulp is normal in appearance with few, if any, inflammatory cells present (Mag. 100X).

occasional scattered dentin chips. Tubular dentin was difficult to find, but when present it was located in the area of most recent reparative dentin deposition. The odontoblast layer was shorter in cell length than the odontoblasts on the lateral pulpal walls. The underlying pulp had few, if any, inflammatory cells (Fig. 2).

Material \#3. - The eight-week response of exposed pulps showed no bridge formation present in any of the specimens. There was no bridging, either partial or complete. The pulpal response was characterized by varying amounts of pulp loss at the exposure site. Most cases showed chronic inflammation and pulp degeneration involving 50\% or more of the pulp. A few cases showed a minimal inflammatory response which was limited to the area beneath the exposure. Reparative dentin was present only on the lateral pulp walls and around dentin chips which were scattered throughout the pulp near the exposure site.
Material \#4. - Two teeth showed some attempt at forming a dentin bridge. In both teeth the dentin deposited was incomplete, atubular in structure, contained many cellular inclusions, and was present at some distance from the exposure site. The adjacent pulpal status was marginal because of a large number of inflammatory cells and necrotic tissue. The remaining five teeth showed no dentin bridging at or near the exposure. The pulpal response was characterized by tissue loss at the exposure site (Fig. 3). In the majority of teeth, chronic inflammatory cells were present in over $50-70 \%$ of the total pulp volume. In the affected area there was marked dilation of vessels and large areas of complete pulp loss.

Material \#5. - In the five teeth observed, no attempt at either partial or complete bridge formation was observed. In the remaining two teeth some areas of calcification deeper from the exposure site were observed (Fig. 4). These deeper areas in the pulp were composed of irregular nontubular dentin with cellular inclusions. In these two teeth beneath the exposure site, the pulp was composed of a moderate-to-severe inflammatory reaction with increased vascularity. The remaining five teeth had no calcification present, and the responses were characterized by varying degrees of pulp loss at the exposure sites. The inflammatory responses involved from 25 to $100 \%$ of the pulp with abscess formation and increased vascularity - a consistent finding.

Material \#6. - One tooth was found to have an incomplete bridge at some distance from the exposure site. The bridge was composed of irregular dentin filled with entrapped cells with several areas of small spaces. Between the areas of reparative dentin the pulp was filled with inflammatory cells and increased vascularity, and the reparative dentin on the adjacent wall was filled with entrapped cells. In another tooth there was a complete bridge. The exposure was very small, and the new bridge was established a short distance from the exposure. The reparative dentin was tubular with a well established odontoblastic layer and predentin zone. The underlying pulp was free of inflammation. The remaining six teeth had no bridges, and the responses can be divided into two groups of three each. The first was characterized by chronic 


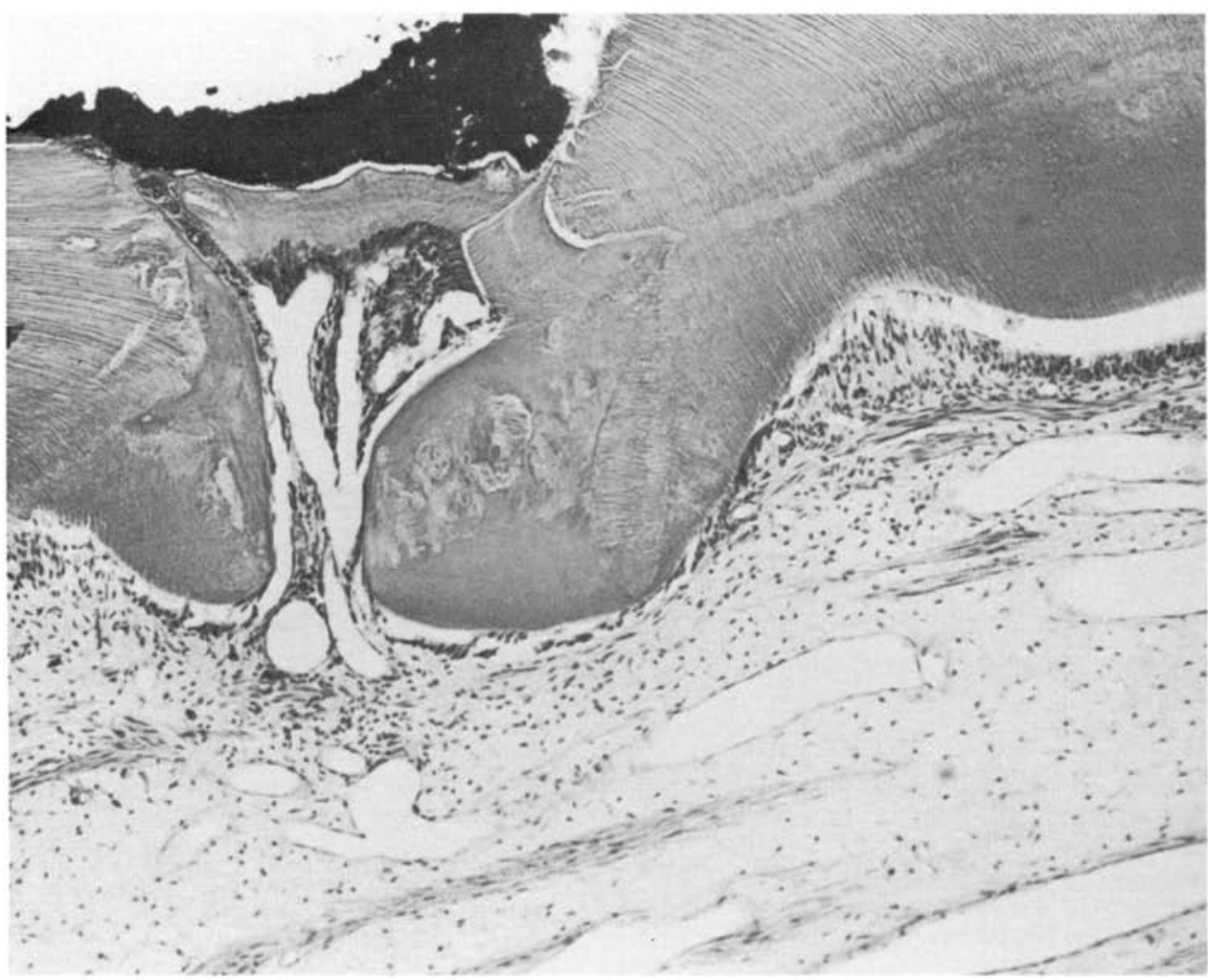

Fig. 2 - Material \#2. This shows a reparative dentin bridge adjacent to the medicament. Reparative dentin can be observed surrounding dentin chips lateral to the exposure. The reparative dentin bridge is atubular, and the pulp tissue is very vascular beneath (Mag. 100X).

inflammation, some abscess formation, and increased vascularity limited to $25 \%$ of the pulp or less. The second group showed a more severe reaction involving $80-100 \%$ of the pulp with some cases having complete pulp loss, while the others had inflammatory response and abscess formation occupying $80 \%$ of the pulp.

Material \#7. - The six teeth observed fell into two categories. In one category, the response was limited to $20 \%$ or less of the pulp. The inflammatory response was moderate with some abscess formation and vascularization; reparative dentin was found around dentin chips and on the lateral walls adjacent to the exposure site. In the other category, $50 \%$ or more of the pulp was involved in the inflammatory response with large areas of pulp loss. Little, if any, reparative dentin could be found on the dentin chips and on the lateral walls. No reparative dentin bridges were observed.

Material \#8. - No bridge formation was seen in any of the six teeth examined. Three teeth had a limited pulpal reaction with a moderate inflammatory response, while the remaining three teeth had abscess formation which involved up to $25 \%$ of the pulp. In these teeth, no reparative dentin was found around the dentin chips and very little on the dentin walls adjacent to the exposure.

Material \#9. - Two teeth showed no bridge formation and a large amount of pulp loss involving $50-80 \%$ of the pulp. The interface between viable and nonviable tissue was composed of a mummified tissue which was irregular in width; the underlying pulp was filled with chronic inflammatory cells. Three teeth demonstrated incomplete bridge formation, which was almost complete but had small areas of non-calcified tissue. The new reparative bridge was always located at some distance from the exposure site, which resulted in a considerable decrease in pulp volume. The remaining three teeth had complete bridges composed of two types. In 


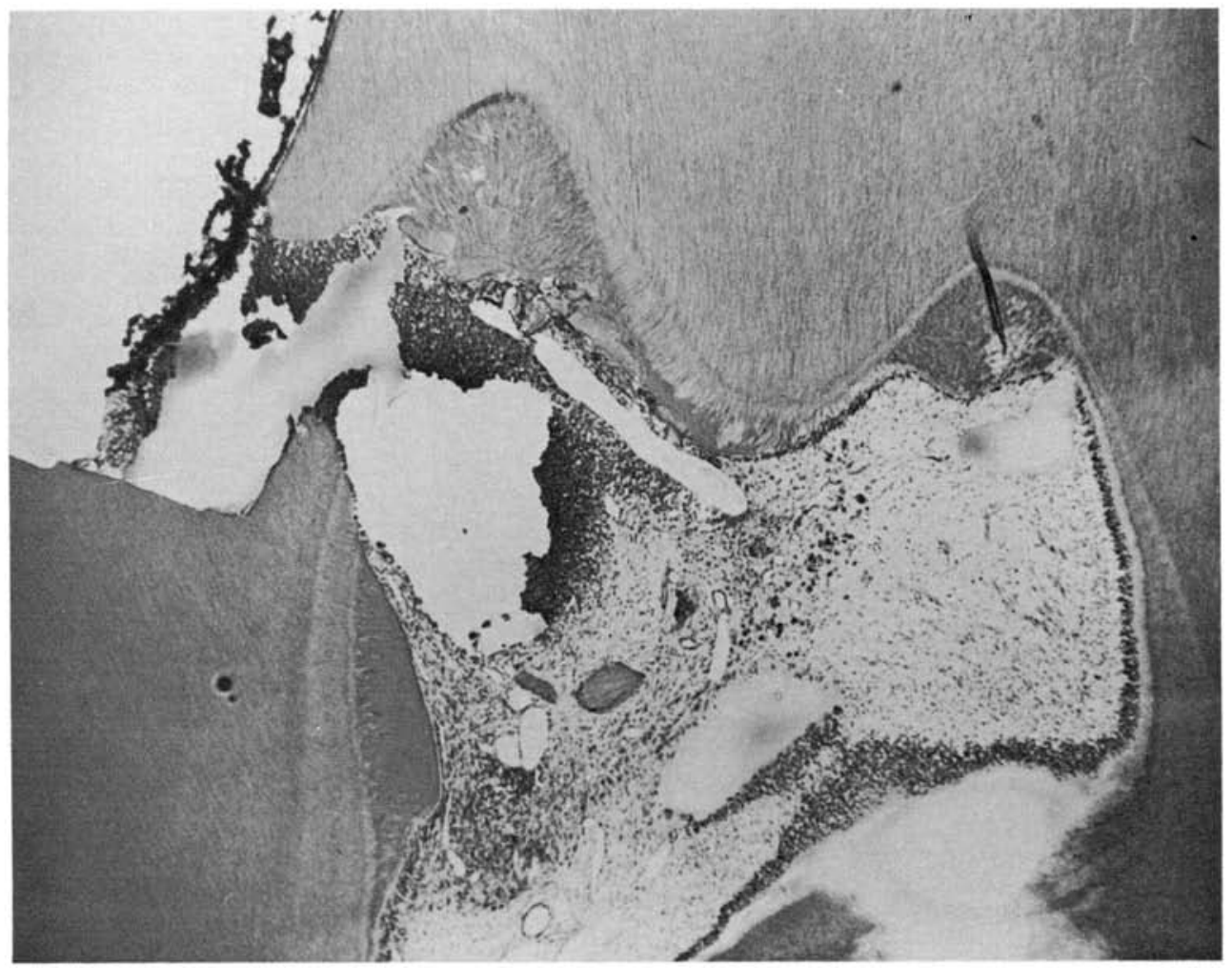

Fig. 3 - Material \#4. This shows a moderately severe pulpal response which involves $50 \%$ of the pulp. No reparative dentin was observed (Mag. 40X).

one case the reparative dentin was tubular in nature with a well established predentin and odontogenic zone. The other type demonstrated complete bridges composed of irregular dentin which was thin and filled with cellular inclusions. Some inflammatory cells were present in the underlying pulp.

Material \#10. - In all teeth, no reparative dentin was observed either along the medicament interface or adjacent to the dentin chips. In five teeth the pulpal response was limited to less than $20 \%$ of the pulp volume. The response was characterized by a minimal amount of tissue loss at the exposure site and a moderate inflammatory response. Medicament could be found in the affected area of the pulp. The remaining two cases showed a more severe response with a large amount of tissue loss at the exposure site and a more severe inflammatory response. In those teeth little, if any, reparative dentin was seen either around the dentin chips or along the walls under the cavity preparations.

Material \#11. - None of the seven teeth showed evidence of bridge formation. The pulpal responses could be divided into two groups. The first group showed a moderate pulpal response. The response was characterized by some tissue loss at the exposure site and a chronic inflammatory response involving up to $25 \%$ of the pulpal tissue. Severe pulpal reactions were evident in the second group. The responses seen here involved 80 $100 \%$ of the pulp with chronic inflammatory response and abscess formation throughout. In this group, small amounts of reparative dentin could be found on the lateral walls beneath the cavity preparation when compared to the first group which had tubular reparative dentin in such comparable areas.

Material \#12. - No dentin bridges were found in any of the eight teeth observed. 


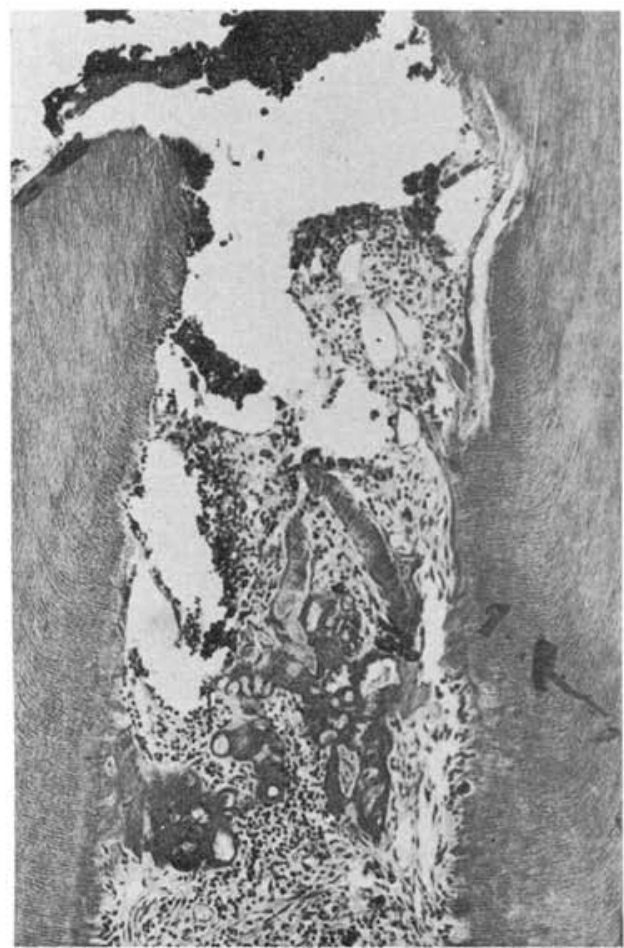

Fig. 4 - Material \#5. This shows a moderate pulpal response with loss of pulp tissue beneath the exposure site. An area of calcification is present in the underlying pulp (Mag. 100X).

The pulp response was similar to that of Material 11 except for the amount of the pulp involved. Four teeth had a pulpal response involving approximately $25 \%$ of the pulp, while the rest had pulpal involvement up to $80 \%$. In the teeth with less involvement, the inflammatory response was moderate with some abscess formation, increased vascularity, and reparative dentin around dentin chips and the walls under the cavity preparation. In the three teeth with the majority of the pulp affected there was no reparative dentin around the dentin chips or on the lateral walls.

\section{Discussion.}

Results from this study have shown that Experimental Life, Dycal, and $\mathrm{CaOH}+$ Saline are the most successful medicaments for stimulating reparative dentin bridges over a non-inflamed exposed pulp. MPC has been shown to be an ineffective pulp capping agent. These findings confirm studies done by Stanley, ${ }^{28}$ Tronstad, ${ }^{29}$ and Heys. ${ }^{18}$

Results show that Synthos and Tricalcium Phosphate (Materials 4, 5, 10, and 11) are not consistent reparative dentin bridge initiators. This differs from a previous report by $\mathrm{Heller}^{34}$ in which he reported good success with Synthos. Heller stated that Synthos is predictable in its ability to cause formation of a dentin bridge with minimal pulpal inflammation, and that Synthos is better able to form dentin bridges than pure $\mathrm{Ca}(\mathrm{OH})_{2}$ and saline. Our findings were unable to show any predictability to bridge formation with Synthos; in fact, pulpal inflammation persisted in considerable amounts. However, this inflammation may be attributed to the MPC placed over the Synthos.

$\mathrm{Ca}(\mathrm{OH})_{2}$ and saline presented a histological response, with pulp loss at the medicament interface and bridge formation occurring at some distance from the material interface. This differs from the response seen with Experimental Life and Dycal, where bridging occurred at the medicament interface without loss of pulp volume. We found with $\mathrm{Ca}(\mathrm{OH})_{2}$ and saline a better bridge formed than with Synthos.

Differences could be observed between the group in which MPC (catalyst and base) was used to cover the medicament paste and the group in which only the MPC catalyst was used. This seems to agree with the findings of Sela et al. ${ }^{36}$ who reported on the use of a separate component of Hydrex on rat pulps. They found the catalyst to be irritating to the pulp. It was our intent to see whether we could improve the effectiveness of the MPC system by adding components and covering these with the catalyst. Our findings indicate that this irritating response was not present. Our use of MPC over the various test medicaments was to apply a layer which would hold the medicament and saline paste in position. Fisher ${ }^{36}$ states that Hydrex's paraffin matrix (MPC is almost identical) is hydrophobic in nature and probably prevents the diffusion of water into the set material. What Fisher is stating is that the set MPC is so tightly bound that the $\mathrm{Ca}$ ion release is minimal, probably explaining its ineffectiveness. ${ }^{36}$

Zinc oxide plus C-AMP (Materials 7 and 
TABLE 1

HISTOLOGICAL RESULTS

\begin{tabular}{|c|c|c|}
\hline & Pulpal Response & Bridging Results \\
\hline $\begin{array}{l}\text { Material \#1 } \\
\text { Experimental Life }\end{array}$ & $\begin{array}{l}4 \text { slight } \\
2 \text { moderate } \\
1 \text { severe and } 1 \text { moderate }\end{array}$ & $\begin{array}{l}4 \text { complete bridges adjacent to medicament } \\
2 \text { incomplete bridges adjacent to medicament } \\
2 \text { no bridges, chronic inflammation adjacent } \\
\text { to medicament }\end{array}$ \\
\hline $\begin{array}{l}\text { Material \#2 } \\
\text { Dycal }\end{array}$ & $\begin{array}{l}3 \text { slight } \\
2 \text { slight and } 1 \text { moderate } \\
2 \text { severe }\end{array}$ & $\begin{array}{l}3 \text { complete bridges adjacent to medicament } \\
3 \text { incomplete bridges adjacent to medicament } \\
2 \text { no bridges, chronic inflammation adjacent } \\
\text { to medicament }\end{array}$ \\
\hline $\begin{array}{l}\text { Material \#3 } \\
\text { MPC }\end{array}$ & 2 moderate and 6 severe & $\begin{array}{l}8 \text { no bridges, chronic inflammation adjacent } \\
\text { to medicament }\end{array}$ \\
\hline $\begin{array}{l}\text { Material } \\
\text { Synthos plus Saline } \\
\text { Covered by MPC }\end{array}$ & $\begin{array}{l}2 \text { severe } \\
5 \text { severe }\end{array}$ & $\begin{array}{l}2 \text { incomplete bridges, chronic inflammation } \\
\text { present } \\
5 \text { no bridges, chronic inflammation adjacent } \\
\text { to medicament } \\
1 \text { no exposure }\end{array}$ \\
\hline $\begin{array}{l}\text { Material \#5 } \\
\text { Tricalcium Phosphate } \\
\text { plus Saline Covered by } \\
\text { MPC }\end{array}$ & $\begin{array}{l}2 \text { severe } \\
5 \text { severe }\end{array}$ & $\begin{array}{l}2 \text { incomplete bridges, chronic inflammation } \\
\text { present between calcification \& medicament } \\
5 \text { bridges, chronic inflammation adjacent } \\
\text { to medicament } \\
1 \text { no exposure }\end{array}$ \\
\hline $\begin{array}{l}\text { Material \#6 } \\
\text { Zinc Oxide plus Saline } \\
\text { Covered by MPC }\end{array}$ & $\begin{array}{l}1 \text { slight } \\
1 \text { moderate } \\
6 \text { severe }\end{array}$ & $\begin{array}{l}1 \text { complete bridge adjacent to medicament } \\
1 \text { incomplete bridge, chronic inflammation } \\
\text { between bridge and medicament } \\
6 \text { no bridges, chronic inf. adj. to medicament }\end{array}$ \\
\hline $\begin{array}{l}\text { Material \#7 } \\
\text { Zinc Oxide - C-AMP plus } \\
\text { Saline Covered by MPC }\end{array}$ & 6 severe & $\begin{array}{l}6 \text { no bridges, chronic inflammation adjacent } \\
\text { to medicament } \\
2 \text { no exposures }\end{array}$ \\
\hline $\begin{array}{l}\text { Material } \# 8 \\
\text { Zinc Oxide - C-AMP plus } \\
\text { Saline covered by MPC } \\
\text { Catalyst }\end{array}$ & 1 slight and 5 severe & $\begin{array}{l}6 \text { no bridges, chronic inflammation adjacent } \\
\text { to medicament } \\
2 \text { no exposures }\end{array}$ \\
\hline $\begin{array}{l}\text { Material } \# 9 \\
\mathrm{Ca}(\mathrm{OH})_{2} \text { plus Saline } \\
\text { Covered by MPC }\end{array}$ & $\begin{array}{l}1 \text { slight and } 2 \text { moderate } \\
2 \text { slight and } 1 \text { moderate } \\
2 \text { severe }\end{array}$ & $\begin{array}{l}3 \text { complete bridges, necrosis between } \\
\text { medicament and bridge } \\
3 \text { incomplete bridges (same as above) } \\
2 \text { no bridges, necrotic tissue adjacent to } \\
\text { medicament }\end{array}$ \\
\hline $\begin{array}{l}\text { Material \#10 } \\
\text { Synthos plus Saline } \\
\text { Covered by MPC Catalyst }\end{array}$ & 7 severe & $\begin{array}{l}7 \text { no bridges, chronic inflammation adjacent } \\
\text { to medicament } \\
1 \text { no exposure }\end{array}$ \\
\hline $\begin{array}{l}\text { Material \#11 } \\
\text { Tricalcium Phosphate } \\
\text { plus Saline Covered by } \\
\text { MPC Catalyst }\end{array}$ & 7 severe & $\begin{array}{l}7 \text { no bridges, chronic inflammation adjacent } \\
\text { to medicament } \\
1 \text { no exposure }\end{array}$ \\
\hline $\begin{array}{l}\text { Material \#12 } \\
\text { Zinc Oxide plus Saline } \\
\text { Covered by MPC Catalyst }\end{array}$ & 2 moderate and 6 severe & $\begin{array}{l}8 \text { no bridges, chronic inflammation adjacent } \\
\text { to medicament }\end{array}$ \\
\hline
\end{tabular}


8) was included in this study to see if it had any beneficial effect. Results show that it did not. Its reason for being tested was based on findings by Suzuki, ${ }^{37}$ who reported on C-AMP as being effective in bone and dentin formation. Watts ${ }^{38}$ tested zinc oxide in rats and found it to be as effective as Dycal in stimulating reparative dentin bridges. This was not found to be the case in the present study. A possible explanation for this may be that the zinc oxide was covered with Dycal, and that the Dycal in combination with the $\mathrm{ZnO}$ was ineffective. In our study we covered the $\mathrm{ZnO}$ with MPC. The difference may be due to the calcium ion release between the two calcium hydroxides.

Table 2 shows the results of a $\mathrm{chi}^{2}$ analysis comparing the histological response and dentin bridging. It shows that there is a significant difference between the type of response and the amount of bridging which has occurred. More bridging is observed with a slight pulpal response than with a moderate response, and more with a moderate than with a severe response. Table 3 shows that no significant difference was present when all 12 materials were compared to the bridging, but Experimental Life, Dycal, $\mathrm{Ca}(\mathrm{OH})_{2}+$ Saline, when compared to the remaining compounds, show a significant difference in their ability to stimulate a reparative dentin bridge.

TABLE 2

$\mathrm{CHI}^{2}$ ANALYSIS OF THE HISTOLOGICAL PULPAL RESPONSES OF MONKEY TEETH COMPARED TO REPARATIVE DENTIN BRIDGE FORMATION

\begin{tabular}{lcc}
\hline \hline Pulpal Response & With Bridge & Without Bridge \\
\hline Slight & 13 & $1^{*}$ \\
Moderate & 7 & $6^{*}$ \\
Severe & 4 & $59^{*}$
\end{tabular}

*The three proportions are statistically significant from equality $(p<0.01)$.

\section{Conclusions.}

In summary, results from this study have shown that most calcium hydroxide (Materials 1 and 2) was effective in healing the pulp and stimulating a reparative dentin bridging. Materials 5,6,10, and 11 were not effective in promoting pulp healing, which
TABLE 3

$\mathrm{CHI}^{2}$ ANALYSIS OF VARIOUS MATERIAL PLACED ON MONKEY TEETH PULPS COMPARED TO REPARATIVE DENTIN BRIDGE FORMATION.

\begin{tabular}{lcc}
\hline \multicolumn{1}{c}{ Material } & $\begin{array}{c}\text { With } \\
\text { Bridge }\end{array}$ & $\begin{array}{c}\text { Without } \\
\text { Bridge }\end{array}$ \\
\hline $\begin{array}{l}\text { Experimental Life } \\
\text { Dycal }\end{array}$ & 6 & $2^{*}$ \\
MPC & 6 & $2^{*}$ \\
$\begin{array}{l}\text { Synthos plus Saline } \\
\text { Covered by MPC } \\
\text { Tricalcium Phosphate } \\
\text { plus Saline Covered by MPC }\end{array}$ & 2 & 8 \\
$\begin{array}{l}\text { Zinc Oxide plus Saline } \\
\text { Covered by MPC }\end{array}$ & 2 & 5 \\
$\begin{array}{l}\text { Zinc Oxide - C-AMP plus } \\
\text { Saline Covered by MPC }\end{array}$ & 0 & 6 \\
$\begin{array}{l}\text { Zinc Oxide - C-AMP plus } \\
\text { Saline Covered by MPC } \\
\text { Catalyst }\end{array}$ & 0 & 6 \\
$\begin{array}{l}\text { Ca(OH) plus Saline } \\
\text { Covered by MPC }\end{array}$ & 6 & $2 *$ \\
$\begin{array}{l}\text { Synthos plus Saline } \\
\text { Covered by MPC Catalyst }\end{array}$ & 0 & 7 \\
$\begin{array}{l}\text { Tricalcium Phosphate } \\
\text { plus Saline Covered by }\end{array}$ & 0 & 7 \\
$\begin{array}{l}\text { MPC Catalyst } \\
\text { Zinc Oxide plus Saline } \\
\begin{array}{l}\text { Covered by MPC } \\
\text { Catalyst }\end{array}\end{array}$ & 0 & 8 \\
\hline
\end{tabular}

*The three proportions are statistically significant from equality $(\mathrm{p}<0.01)$.

contradicts an earlier report ${ }^{34}$ on Tricalcium Phosphate success in promoting pulp healing.

\section{REFERENCES}

1. RZESZOTARSKI, J.S.: Clinical and Histologic Studies of Partial Pulp Amputation, The Bur 39(2):39-69, 1939.

2. BERGER, J.E.: Pulp Tissue Reaction to Formocresol and Zinc Oxide Eugenol, $J$ Dent Child 32:13-28, 1st Quart., 1965.

3. KAPUR, K.K.; SHAPIRO, S.; and SHKLAR, D.: Response of Human Dental Pulp to Various Physical and Chemical Agents: A Correlated Clinical and Histopathologic Study, Oral Surg 17:640-649, 1964.

4. SELA, J. and ULMANSKY, M.: Reaction of Normal and Inflamed Dental Pulp to Calxyl and Zinc Oxide Eugenol in Rats, Oral Surg 30:425-430, 1970 .

5. MAGNUSSON, B.: Therapeutic Pulpotomy in Primary Molars: Clinical and Histological 
Follow-up. II. ZOE as a Wound Dressing, Odont Revy 24:45-54, 1971.

6. WEISS, M.B. and BJORUATIN, K.: Pulp Capping in Deciduous and Newly Erupted Permanent Teeth of Rhesus Monkeys, Oral Surg 29:769-775, 1970.

7. TRONSTAD, L. and MJÖR, I.A.: Pulpal Reaction to Calcium Hydroxide Containing Materials, Oral Surg 33(6):961-965, 1972.

8. GLASS, R. and ZANDER, H.A.: Pulp Degeneration and Necrosis May Occur without Any Chemical Signs or Symptoms, Pulp Healing, $J$ Dent Res 28:97, 1949.

9. HEYS, D.R.; HEYS, R.J.; and RACETTE, W.A.: A Histological Evaluation of Ten Restorative Compounds, The University of Michigan, Master's Thesis, 1975.

10. McWALTER, D.M.; EL-KAFRAWY, A.H.; and MITCHELL, D.F.: Pulp Capping in Monkeys with a Calcium Hydroxide Compound. An Antibiotic and a Polycarboxylate Cement, Oral Surg 36:90-100, 1973.

11. SAFER, D.: Histological Evaluation of New Dental Materials, The University of Michigan, Master's Thesis, 1971.

12. SEELING, A.: The Formation of Calcified Tissue in Dental Pulps, NY State Dent $J$ 22(6):260-272, 1956 .

13. BERMAN, D.S. and MASSLER, M.: Experimental Pulpotomies in Rat Molars, $J$ Dent Res 37:229-242, 1958.

14. VIA, W.: Evaluation of Deciduous Molars by Treated Pulpotomy and Calcium Hydroxide, $J A D A$ 50:34-43, 1955.

15. QUIGLEY, M.B.: Experimental Exposure of Hamster Pulps, Oral Surg 9:1127-1131, 1956.

16. BARKER, C.W. and LOCKETT, B.C.: An Unusual Response of Dog Pulp to Calcium Hydroxide, Oral Surg 32(5):785-799, 1971.

17. SCHRÖDER, U. and GRANATH, L.: On Enamel Dentin Resorption in Deciduous Molars Treated by Pulpotomy and Capped with Calcium Hydroxide, Odonto Revy 22(2):179-189, 1971.

-18. .HEYS, D.R.; HEYS, R.J.; COX, C.F.; and AVERY, J.K.: Response of Four Calcium Hydroxides on Monkey Pulps, $J$ Oral Path, 9:372-379, 1980.

19. SAYEGH, F.A. and REED, A.J.: Correlated Chemical and Histological Evaluation of Hydrex in Pulp Therapy, $J$ Dent Child 34:471-477, 1967.

20. PHANEUF, R.A.; SPENCER, F.W.; and MORRIS, R.P.: A Comparative Histological Evaluation of the Calcium Hydroxide Preparations on the Human Primary Dental Pulp, $J$ Dent Child $34: 1,61-76,1968$.

21. HIRSCHFELD, Z.; SELA, J.; and ULMANSKY, M.: Hydrex and Its Effect on the Pulp, Oral Surg 34(2):364-371, 1972.

22. OSTROM, C.A. and LYON, H.W.: Pulpal Response to Chemically Treated Heterogene- ous Bone in Pulp Capping Sites, Oral Surg 15(3):362-376, 1962.

23. ROBERTS, M.W.; MOFFA, J.P.; HULL, J.R.; and LILLY, G.E.: An Evaluation of a Zinc Oxide and Eugenol Cement Containing O-Ethoxylbenzoic Acid on Human Deciduous Dental Pulp, Oral Surg 36(3):416-421, 1973.

24. ZANDER, H.A.: Reaction of Pulp to Calcium Hydroxide, J Dent Res 18:373, 1939.

25. CASTAGNOLA, L. and ORLAY, H.G.: Direct Capping of the Pulp and Vital Amputation, $B r$ Dent $J$ 78(12):324-330, 1950.

26. MAGNUSSON, B.: Therapeutic Pulpotomy in Primary Molars, Odonto Revy 21(4):415$431,1970$.

27. LANGER, M.; ULMANSKY, M.; and SELA, J.: Behavior of Human Dental Pulp to Calxyl With or Without Zinc Oxide Eugenol, Arch Oral Biol 15:189-194, 1970.

28. STANLEY, H.R. and LUNDY, T.: Dycal Therapy for Pulp Exposures, Oral Surg 37(5): 818-827, 1972.

29. TRONSTAD, L.: Reaction of the Exposed Pulp to Dycal Treatment, Oral Surg 36(6): 945-953, 1974

30. ULMANSKY, M. and SELA, J.: Response of Pulpotomy Wound in Normal Human Teeth to Successively Applied Ledermix and Calxyl, Arch Oral Biol 16:1393-1398, 1971.

31. GARDNER, D.C.; MITCHELL, D.F.; and McDONALD, R.E.: Treatment of Pulps of Monkeys with Vancomycin and Calcium Hydroxide, J Dent Res 50(5):1273-1277, 1971.

32. COX, C.F.; HEYS, D.R.; and HEYS, R.J.: Gravity Perfusion Technique for Lab Animals, Lab Animals 6(4):18-22, July, 1977.

33. MJÖR, I. and TRONSTAD, L.: Experimentally Induced Pulpitis, Oral Surg 34(1): 102-108, 1972.

34. HELLER, A.L.; KOENINGS, J.F.; BRIL. LIANT, J.D.; MELFI, R.C.; and DRISKELL, T.D.: Direct Pulp Capping of Permanent Teeth in Primates Using Resorbable Form of Tricalcium Phosphate Ceramic, $J$ Endo 1(3): 95-101, 1975.

35. SELA, J.; HIRSCHFELD, Z.; and ULMANSKY, U.: Reaction of the Rat Molar Pulp to Direct Pulp Capping With the Separate Components of Hydrex, Oral Surg 50(1):118-122, 1973.

36. FISHER, F.J. and McCABE, J.F.: Calcium Hydroxide Base Materials. An Investigation into the Relationship Between Chemical Structure and Antibacterial Properties, $\mathrm{Br}$ Dent $J$ 144(11):341-344, 1978.

37. SUZUKI, A. and MASANOBU, I.: Effect of Dibutyryl Cyclic AMP on Formation of Dentin and Bone in Parathyroidectomized Rats, Calcif Tiss Res 15:168, 1974.

38. WATTS, A. and PATERSON, R.C.: Simple Metabolic Compounds as Pulp Capping Agents, Oral Surg 48(6):561-563, 1979. 